\title{
PROPOSAL OF A METHOD FOR DETECTION OF A DAMAGED HYDRAULIC SHOCK ABSORBER IN A VEHICLE'S SUSPENSION SYSTEM
}

\author{
Mykola Gorbunov ${ }^{\dagger, 1}$, Ján Dižo ${ }^{2, *}$, Miroslav Blatnický², Kateryna Kravchenko², Stanislav Semenov ${ }^{1}$ Evgeny Mikhailov $^{1}$ \\ ${ }^{1}$ Volodymyr Dahl East Ukrainian National University, Severodonetsk, Ukraine \\ ${ }^{2}$ University of Zilina, Zilina, Slovak Republic \\ *E-mail of corresponding author: jan.dizo@fstroj.uniza.sk
}

\section{Resume}

In principle, every vehicle is equipped by a suspension system, which usually consists of springs and shock absorbers. The main purpose of the suspension system is to eliminate vibration of sprung and unsprung masses. Therefore, the proper operation conditions of the shock absorbers affect in a fundamental way total running properties of vehicles. However, during operation, shock absorbers are being worn out or they can even be damaged. Then, such a situation is unwanted and it has to be detected as soon as possible. The content of this article is focused on analysis of vehicles' shock absorbers defects. Methods for detection of possible shock absorbers faults are presented. Further, a proposal of the method for detection of a state of a hydraulic shock absorber during its operation is presented. The method uses identification of the temperature change of a hydraulic shock absorber during operation.

Available online: https://doi.org/10.26552/com.C.2022.1.B41-B48

\section{Article info}

Received 13 May 2021

Accepted 27 June 2021

Online 26 October 2021

\section{Keywords:}

new method, hydraulic shock absorber, vehicle,

damage detection

ISSN 1335-4205 (print version)

ISSN 2585-7878 (online version)

\section{Introduction}

Diagnostics and control of the technical conditions of transport facilities is an essential attribute of their operation, because due to comprehensive monitoring, the necessary level of reliability, safety and stability of freight and passengers transport can be achieved [1-2]. An important parameter of technical conditions of vehicles, which determines the comfortable performance and affects the safety of transport, is efficiency of the shock absorbers, which are used to improve the dynamic qualities of vehicles through use of damping properties of their structural elements [3-5].

The shock absorbers are designed to compensate forces that cause oscillations of a body of a vehicle during its movement. The damping of the body oscillations energy must be performed simultaneously in three directions with respect to the straight-line movement of a vehicle itself. A locomotive can be equipped by as many as 32 shock absorbers. In the case of defective conditions of shock absorbers, a spring suspension does not ensure the operation of railway vehicles within the defined running smoothness and may endanger the transport safety. The presence of a defective shock absorber increases wear on elements of vehicles, adversely affecting a track and leads to a need for a speed reduction. Regarding the absence of the needed methodology for determining the failure of shock absorbers during operation in practice, there are such situations, when $50 \%$ of defective shock absorbers per locomotive exist. The change of their temperature or the gradient of the heating rate of any particular object during the vehicle running is one of the important characteristics of the working shock absorbers [6-9].

\section{Vehicles' suspension system}

Vehicles suspension system absorbs shocks and vibrations, which are generated during the vehicle movement on an uneven track. Track unevenness causes quite rough and fast shocks, which are transmitted to the suspension system and transformed to soft and damped deviations of individual vehicle's body [10-11].

The suspension system of a vehicle affects the running safety, ride comfort for passengers and loading of a track [12-15]. If the suspension system works properly, it ensures the constant contact of wheels with a track. It means, that all the forces in the wheel/track contact can be transmitted to the track [16-18], i.e. driving forces, guiding forces and braking forces [19$20]$. Thus, the proper function of all the components of a vehicle suspension system is one of the most important factors for safety and comfort operation of vehicles [21].

As it was mentioned above, the track unevenness causes movements of a vehicle. Profiles of unevenness 


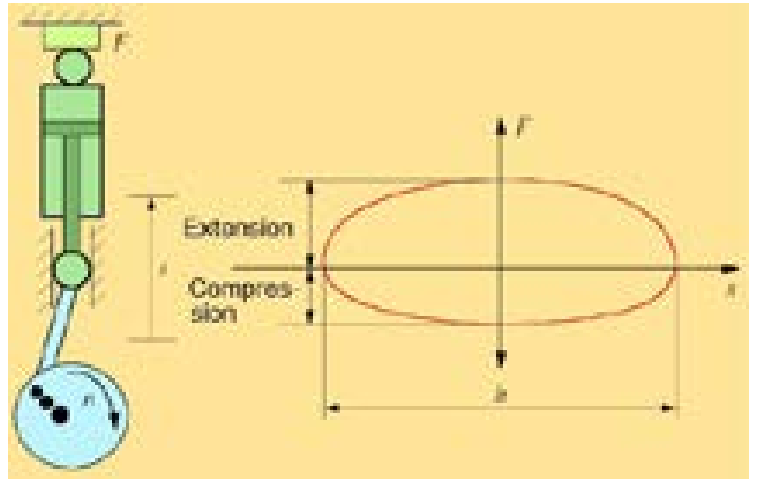

Figure 1 Operating characteristics of a shock absorber: $F$ - force; $s$ - piston movement; $h$ - full stroke

of roadway surfaces or railway tracks are irregular and in the point of view of the statistic dynamics, unevenness are stochastic [22-25]. When the vibration properties of vehicles are investigated, sometimes a single unevenness or impact is considered [26]. Based on numerous research, such unevenness can lead to significantly worse running properties of vehicles and even to an accident [27-28].

Generally, the suspension system of a vehicle consists of springs and shock absorbers. While spring ensures the required positions of individual components of a vehicle with respect to each other and allow their mutual movements in determined directions, the main functionality of the shock absorbers is to reduce amplitudes and frequencies of generated vibrations.

Based on described above, the proper operation of the shock absorbers is extremely important in terms of running properties of vehicles. In the opposite case, the insufficiently effective shocks absorbers or even damaged shock absorbers can cause a number of deficiencies [2931], among others the following:

- Time extension of vibration of individual bodies of a vehicle while running on track unevenness,

- Excessive vibration of a vehicle body, when it runs on successive track unevenness,

- Large deviations of a vehicle body at the improper frequencies generate excessive values of accelerations, which deteriorate the ride comfort for passengers [15, 32],

- Due to high amplitudes of vibrations, a wheel can lose the contact with a track, which means really dangerous situation in terms of the running safety,

- It leads to the worsen effectiveness of braking and directional stability of a vehicle (a normal force is lower) and causes a danger of a skid mainly during running in curves [33].

\section{Methods for identification of a damaged shock absorber}

Hydraulic shock absorbers undergo maintenance as a part of the system of the preventive maintenance [34-35]. Their premature failures are detected during the scheduled inspections, while, as a rule, $\mathrm{t}$ attention is paid to traces of oil and external damage. Methods for testing the shock absorbers directly on a vehicle are being researched, which would make possibility of repairing according to their technical conditions.

The attention is focused on development of a fundamental database of shock absorbers damages, since only incomplete information was available about their type and numbers. A database of damage types and characteristics is created. It is used in modelling the characteristics of shock absorbers of wagon oscillations. The simulation is carried out based on characteristics of the real shock absorbers, which are then prepared for experiments on a roller stand, as well as by a measuring wagon.

Objective monitoring of the performance of hydraulic shock absorbers is carried out on specialized stands using the harmonic oscillation method with diagram recording. A diagram determines parameters of the resistance and then it compares them to the standard values, resistance forces, their symmetry on the extension-compression strokes and maximum values in the valve mode, possible defects in a shock absorber.

Currently, studies of the damping ability in the most studies are performed only according to the performance characteristics (Figure 1) in compliance with the secondary data, in the construction of which, both in working diagrams and experimentally, substantial inaccuracies are allowed, do not provide a sufficiently adequate idea for the real view of the absorbed and scattered energy by the shock absorbers for the cycle of oscillatory motion of a vehicle [36-38].

The working diagram is recorded in these coordinates: $y$ - axis is the piston movement; $x$ - axis is the resistance force. In the case of a working hydraulic shock absorber in the throttle mode, the diagram has the form of a closed ellipse and in the valve mode it comes closer to a rectangle (Figure 2), where $F$ is the damping force, $h$ is a piston stroke in a damper, $L_{e}$ is value of a damper expansion and $L_{c}$ is a damper compression.

The area of the ellipse reflects the work of the forces of the shock absorber resistance:

$W=\pi \cdot \alpha \cdot F(\alpha, \omega)$ 
a)

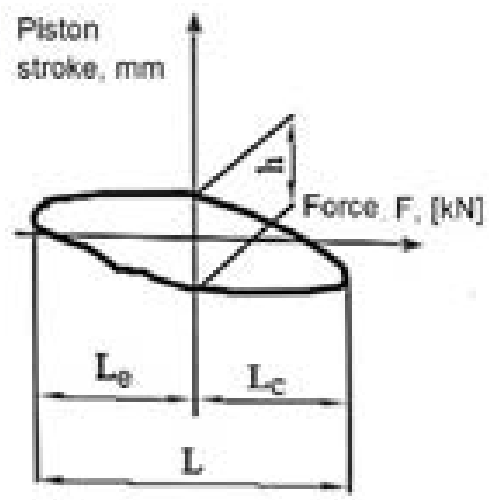

b)

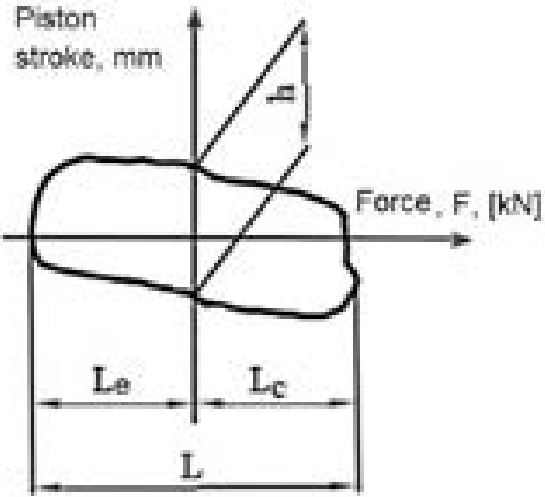

Figure 2 Working diagrams of the hydraulic shock absorbers: $a$ - throttle mode, $b$ - valve mode

Table 1 Analysis of diagrams of hydraulic shock absorbers on a stand at various working modes

Form of a diagram, when: $\quad$\begin{tabular}{c} 
Failure \\
\hline$v_{e 1}=0.04-0.06 \mathrm{~m} \cdot \mathrm{s}^{-1}$
\end{tabular}

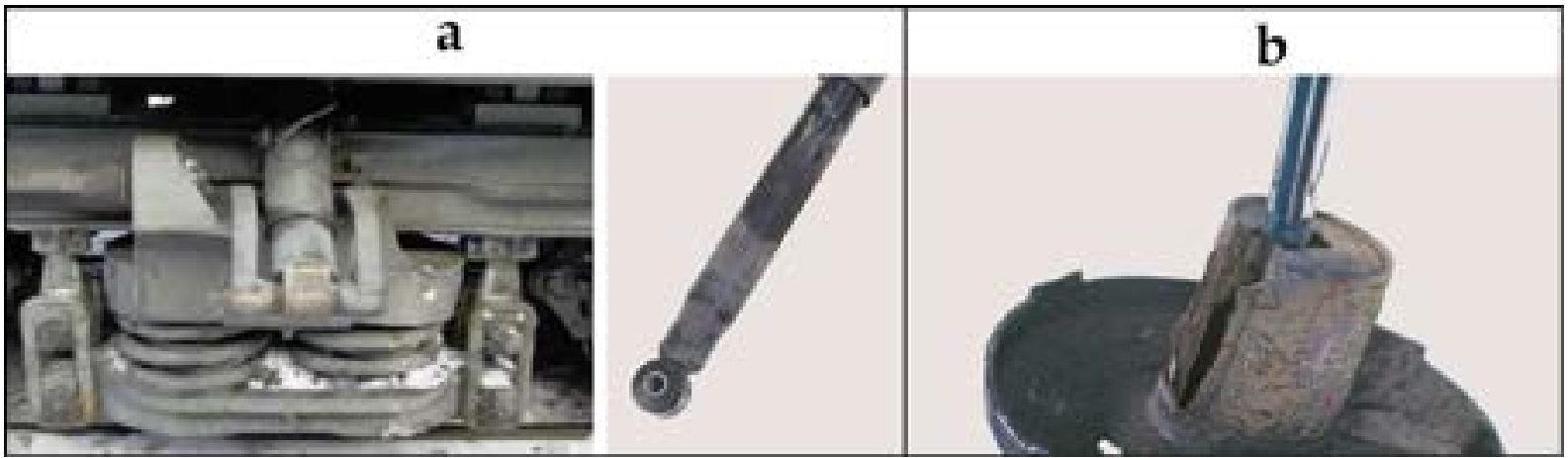

Figure 3 Examples of damaged hydraulic shock absorbers: a) leakage of absorber's oil, b) a broken piston rod

i.e. the energy efficiency rating of the shock absorber $(\alpha$ - oscillation amplitude, $\omega=2 \cdot \pi \cdot f$ - angular frequency, $f$ - oscillation frequency from 1 to $4 \mathrm{~Hz}$ ) [39]. The length of the diagram, at a given scale along the $y$-axis, represents the maximum resistance - the total resistance from the extension and compression stroke $2 \cdot F(\alpha, \omega)=2 \cdot F_{m}$ - the force indicates the inelastic shock absorber resistance.

The most advanced method for determining faults of the shock absorbers is use of the bench equipment. To do this, the shock absorbers have to be removed from a vehicle, installed and mounted on the test bench. Next, the shock absorber loads are applied and the working diagrams of its operation are recorded. The obtained data are compared to the sample diagrams of properly working shock absorbers. As a result, the state of the shock absorber and/or internal and external shock absorber defects are determined. Outer defects are also determined by observation a shock absorber during the testing process on the test stand. An infringement of required form indicates the presence and the form of a defect (Table 1, Figure 3).

Stand "ENGA" type SIL-02-01 is designed for testing the hydraulic shock absorbers of locomotives, passenger wagons, metro wagons, etc. Tests are carried out by harmonic oscillations at an installation angle of the shock absorber from $0^{\circ}$ to $90^{\circ}$, by constructing the working diagram of the hydraulic shock absorber in a test. 


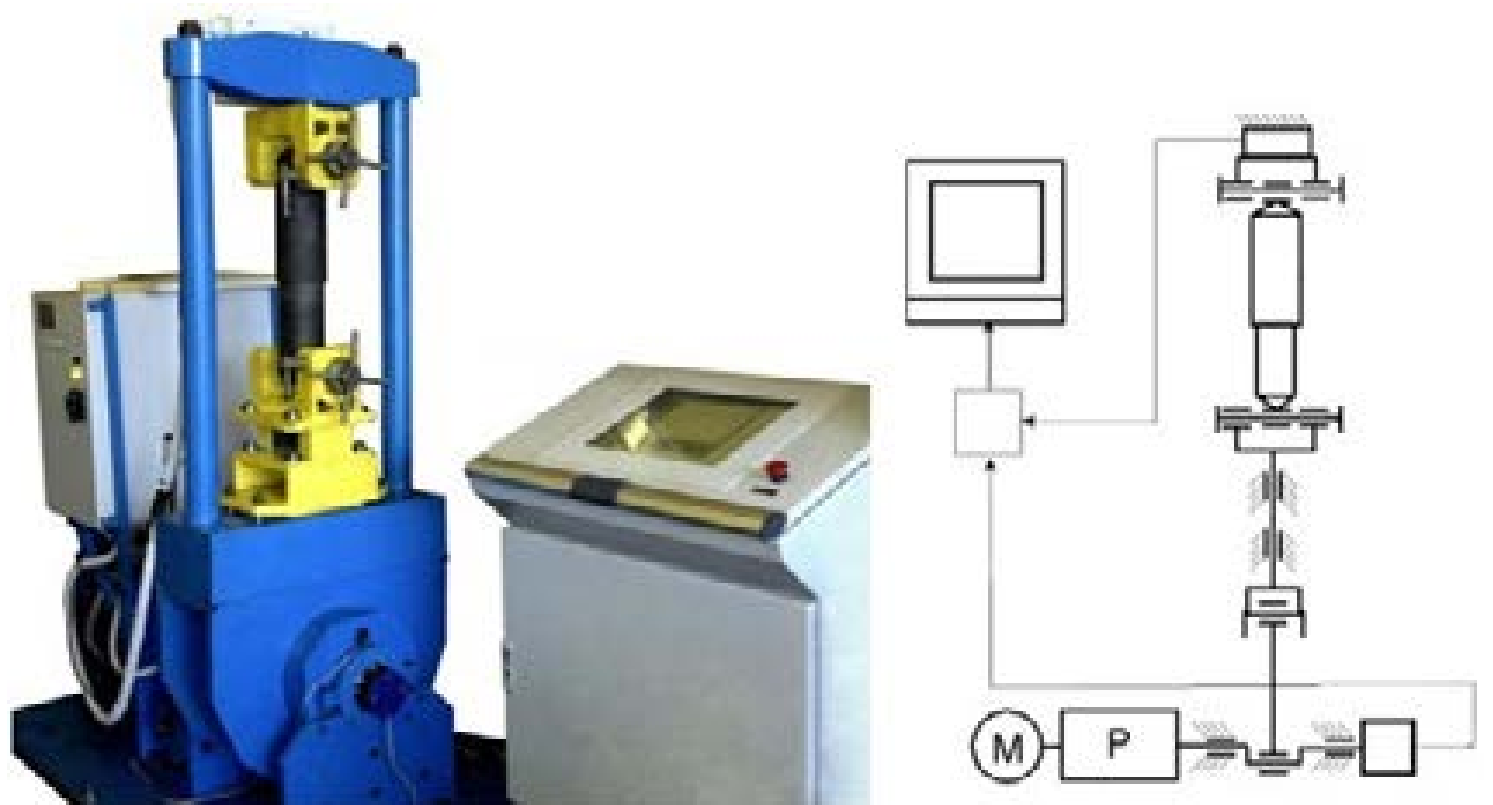

Figure 4 An example of a test stand for the damage detection of a hydraulic shock absorber

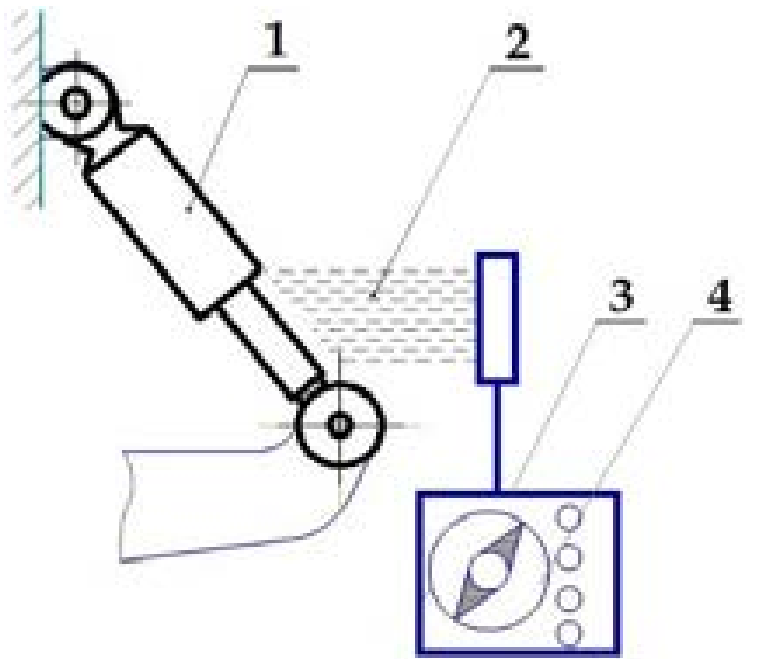

Figure 5 The device for temperature measuring of a shock absorber: 1 - shock absorber, 2 - emitted infrared rays, 3 - radiometer, 4 - receiver

Figure 4 shows the ENGA test stand [40]. The test bench consists of a test module, control module and registration module. The test module consists of the base and a frame of a portal type. In the lower part of the frame, a gearbox of the power drive, the crank mechanism, the fixing mechanism of the lower eye of the tested hydraulic shock absorber, the gearbox for changing the angle inclination, a brake mechanism, a position sensor, sensors of the vertical position and counting of the angle of the stand and the power module, are located. In the upper part of the test module, the fixing mechanism of the upper eye of the tested hydraulic shock absorber, a force-measuring device and a micro-controller module, are located. The control and registration module form a special rack with a system unit, a monitor, a keyboard and a printer.

The study [41] discloses a method for evaluating the damping capacity of the hydraulic shock absorbers.
The method consists of statistical processing of measurements of experimental diagrams. The diagrams are created in the process of experimental tests with different scale and speeds of the piston. Herewith, the number of measurements should be sufficient to ensure the statistical reliability of results. For data processing, the method of regression analysis is used.

Monitoring of technical conditions of the shock absorber can also be performed according to the values of accelerations of the unsprung mass of a vehicle oscillatory motion during its running on track unevenness [42-43]. This method involves comparing information on one hand from sensors, which measure accelerations of the oscillatory motion of the unsprung mass of a vehicle when running on unevenness and, on the other hand, from sensors mounted on the body. The microcontroller processes the results using the mathematical method of the spectral analysis [44-45]. If a disagreement arises 
between the theoretical and experimental power spectral density of the vertical accelerations of the sprung mass, the microcontroller sends a signal to an information board and it shows which shock absorber is failed.

Diagnostics of the shock absorbers is obtained with help of reliable information on their technical condition, based on the fact, that their failures are detected and prevented in a timely manner. Especially important are the diagnostic methods for monitoring the performance of hydraulic shock absorbers without removing them from bogies and without disassembling.

Diagnostic parameters that characterize the technical state of the shock absorbers, are the required amount of working fluid, the intensity of infrared radiation from heating and the background noise of fluid throttling. Measurement of these parameters is carried out on diagnostic devices. Moreover, a radiometer is used for determining the shock absorbers' heating.

The working principle is shown in Figure 5. During operation, the shock absorber (1) heats up and emits infrared rays (2), which are absorbed by the receiver (3). After amplification and transformation of a signal in the radiometer (4), they are registered by the indicator arrow. According to the level of temperature, the indicator determines the operation capability of the shock absorber.

\section{Development of a method for detection of the damaged shock absorber}

The main problem with using the methods presented above for determination of a properly working shock absorber is the inability to detect a faulty shock absorber during the operation. As it is known, one of the extended defects of vibration shock absorbers is the leakage of the working fluid. As a result, the vehicle runs with idle shock absorbers until the vehicle's maintenance [42]. Accordingly, the dynamics, smoothness, comfort and effects related with them are deteriorated [46-48].

The research is based on the task of reducing costs, labor-intensive maintenance, improving the quality of maintenance, reducing the time to restore the operational condition of vehicles with timely detection of the idle shock absorbers and their subsequent replacement during operation, improving the economic efficiency of operation, transportation and help to carriers to secure themselves against accidents on tracks and breakdowns during operation [49-51].

The method is proposed for determining a defective shock absorber, which is as follows:

- Determination of a failure of a shock absorber in operation; the mounted shock absorber is painted with a heat-sensitive color, activity of which depends on temperature. The heat-sensitive colors change their crystal lattice when heated and, as a result, change color (based on the change in the absorption spectrum due to a phase transition). One form of production of the thermal indicator inks are the wax pencils.

- The sensors for detecting the ambient temperature; the temperature of the shock absorber and the color change of the vibration shock absorber are installed and connected to a data processing unit (DPU). The DPU software calculates the permissible heat of the working shock absorber depending on the ambient temperature.

- For verification of a relevant results of the method is used a sensor, which reacts to colors of the shock absorber. The software processes information from this sensor and compares it to the temperature sensor.

- After processing information in the DPU, information about the operational capability of the shock absorber is shown on the control display of a mobile unit.

- To further check the operation of the shock absorber, the operator performs an external inspection of it immediately after the vehicle stops and by its color confirms the state of the shock absorber and records that in a fault book.

\section{Conclusion}

According to results of the study, it was determined, that a large number of shock absorbers do not work properly. This phenomenon worsens the running characteristics of a vehicle and impairs its running dynamics. There are many methods for eliminating the non-working shock absorbers, but the main ones are based on using the bench equipment. In this case, it is necessary to remove a shock absorber from a vehicle. This complicates the procedure for identifying a defective shock absorber. A method is proposed for diagnostics of the shock absorbers on vehicles, based on an assessment of the shock absorber's temperature. This method allows:

- Reducing costs,

- Reducing maintenance effort,

- Improving the maintenance quality,

- Reducing time for restoring the operation capability condition of vehicles with timely detection of nonworking shock absorbers and their subsequent replacement during operation and

- Increase the economic efficiency of the operation of vehicles and helps to carriers to secure themselves against accidents on tracks and breakdowns during operation.

\section{Acknowledgement}

The authors of the article express their deep gratitude for the joint work with the outstanding professor Mykola Gorbunov. The technical ideas of the article have 
originated as the results of scientific discussion with him. His irreplaceable contribution to development of modern science is expressed by the non-standard and creative nature of the proposed technical solutions, some of which are also presented in this article.

This research was supported by the Cultural and Educational Grant Agency of the Ministry of Education of the Slovak Republic in the project No. KEGA 023ŽU. 4/2020: "Development of advanced virtual models for studying and investigation of transport means operation characteristics".

This research was also supported by the Slovak Research and Development Agency of the Ministry of Education, Science, Research and Sport of the Slovak Republic in Educational Grant Agency of the Ministry of Education of the Slovak Republic in the project No. VEGA 1/0558/18: "Research of the interaction of a braked railway wheelset and track in simulated operational conditions of a vehicle running in a track on the test bench".

\section{References}

[1] GERLICI, J., SAKHNO, V., YEFYMENKO, A., VERBITSKII, V., KRAVCHENKO, A., KRAVCHENKO, K. The stability analysis of two-wheeled vehicle model. In: 22nd Slovak-Polish Scientific Conference on Machine Modelling and Simulations MMS 2017: proceedings. 2017.

[2] SAKHNO, V., POLIAKOV, V., TIMKOV, O., KRAVCHENKO, O. Lorry convoy stability taking into account the skew of semitrailer axes. Transport Problems [online]. 2016, 11(3), p. 69-76. eISSN 2300-861X. Available from: https://doi.org/10.20858/tp.2016.11.3.7

[3] LOVSKA, A., FOMIN, O., PISTEK, V., KUCERA, P. Dynamic load modelling within combined transport trains during transportation on a railway ferry. Applied Sciences [online]. 2020, 10(16), 5710. eISSN 2076-3417. Available from: https://doi.org/10.3390/app10165710

[4] LOVKSA, A., FOMIN, O., PISTEK, V., KUCERA, P. Dynamic load and strength determination of carrying structure of wagons transported by ferries. Journal of Marine Science and Engineering [online]. 2020, 8(11), 902. eISSN 2077-1312. Available from: https://doi.org/10.3390/jmse8110902

[5] STASTNIAK, P., MORAVCIK, M. Development of two types of freight wagons with bogies for non-standard wheelbase or track wheelset, complying with the criteria for interoperability, environmental issues, safety and reliability. In: 23rd International Conference on Current Problems in Rail Vehicles: proceedings. 2017. p. 401-408.

[6] ALEGRE, D. M., KOROISHI, E. H., MELO, G. P. Experimental fault diagnosis in systems containing finite elements of plate of Kirchhoff by using state observers methodology. Journal of Physics: Conference Series [online]. 2015, 628(1), 012022. ISSN 1742-6588, eISSN 1742-6596. Available from: https://doi.org/10.1088/1742$6596 / 628 / 1 / 012022$

[7] VAICIUNAS, G., BUREIKA, G., STEISUNAS, S. Rail vehicle axle-box bearing damage detection considering the intensity of heating alteration. Eksploatacja i Niezawodnosc-Maintenance and Reliability [online]. 2020, 22(4), p. 724-729. ISSN 1507-2711. Available from: http://dx.doi.org/10.17531/ein.2020.4.16

[8] ZHAO, Z., WU, B., ZHOU, T. Feature analysis of degradation signal of rolling stock lateral damper. Information [online]. 2020, 11(6), 298. eISSN 2078-2489. Available from: https://doi.org/10.3390/info11060298

[9] SUCHANEK, A., HARUSINEC, J., LOULOVA, M., STRAZOVEC, P. Analysis of the distribution of temperature fields in the braked railway wheel. MATEC Web of Conferences [online]. 2018, 157, 02048. eISSN 2261-236X. Available from: https://doi.org/10.1051/matecconf/201815702048

[10] SAGA, M., VASKO, M., HANDRIK, M., KOPAS, P. Contribution to random vibration numerical simulation and optimisation of nonlinear mechanical systems. Scientific Journal of Silesian University of TechnologySeries Transport [online]. 2019, 103, p. 143-154. ISSN 0209-3324, eISSN 2450-1549. Available from: https://doi.org/10.20858/sjsutst.2019.103.11

[11] REZAZADEH, A., MORADI, H. Design of optimum vibration absorbers for a bus vehicle to suppress unwanted vibrations against harmonic and random road excitations. Scientia Iranica [online]. 2021, 28(1), p. 241-254. ISSN 1026-3098. Available from: https://doi.org/10.24200/SCI.2020.50911.1911

[12] PAVELCIK, V., BARTA, D., SAPIETA, M. Proposal of a mechanism for car seat movement. Advances in Science and Technology-Research Journal [online]. 2020, 14(1), p. 50-57. ISSN 2299-8624. Available from: https://doi.org/10.12913/22998624/113286

[13] ZEHELEIN, T., HEMMERT-POTTMANN, T., LIENKAMP, M. Diagnosing automotive damper defects using convolutional neural networks and electronic stability control sensor signals. Journal of Sensor and Actuator Networks [online]. 2020, 9(1), 8. eISSN 2224-2708. Available from: https://doi.org/10.3390/jsan9010008

[14] GARDYNSKI, L., CABAN, J., BARTA, D. Research of composite materials used in the construction of vehicle bodywork. Advances in Science and Technology-Research Journal [online]. 2018, 12(3), p. 181-187. ISSN 2299-8624. Available from: https://doi.org/10.12913/22998624/92096 
[15] SUCHANEK, A., HARUSINEC, J., LOULOVA, M. Evaluation of passenger riding comfort of a rail vehicle by means dynamic simulations. In: 23rd Polish-Slovak Scientific Conference on Machine Modelling and Simulations MMS: proceedings. 2018.

[16] KORZEB, J., CHUDZIKIEWICZ, A. Evaluation of the vibration impacts in the transport infrastructure environment. Archive of Applied Mechanics [online]. 2015, 85(9-10), p. 1331-1342. ISSN 0939-1533, eISSN 1432-0681. Available from: https://doi.org/10.1007/s00419-015-1029-0

[17] SAVARESI, D., FAVALLI, F., FORMENTIN, S., SAVARESI, S. M. On-line damping estimation in road vehicle semi-active suspension systems. In: 9th IFAC Symposium on Advances in Automotive Control AAC 2019: proceedings. 2019.

[18] KOJIMA, T., SUGAHARA, Y. Fault detection of vertical dampers of railway vehicle based on phase difference of vibrations. Quarterly Report of RTRI (Railway Technical Research Institute) [online]. 2013, 54(3), p. 139-144. ISSN 0033-9008, eISSN 1880-1765. Available from: https://doi.org/10.2219/rtriqr.54.139

[19] GERLICI, J., TKACHENKO, V., SAPRONOVA, S., LACK, T. Steerability research of railway vehicles. In: 24th International Conference on Current Problems in Rail Vehicles: proceedings. p. 145-152. 2019.

[20] TKACHENKO, V., SAPRONOVA, S. Steerability of railway vehicles. Transport Problems. 2007, 2(4), p. 9-16. ISSN 1896-0596, eISSN 2300-861X.

[21] SAPRONOVA, S., TKACHENKO, V., KRAMAR, N., VORONKO, A. Regularities of shaping of a wheel profile as a result of deterioration of the rolling surface in exploitation. Transport Problems. 2008, 3(4), p. 47-54. ISSN 1896-0596, eISSN 2300-861X.

[22] LEITNER, B., DECKY, M., KOVAC, M. Road pavement longitudinal evenness quantification as stationary stochastic process. Transport [online]. 2019, 34(2), 195-203. ISSN 1648-4142, eISSN 1648-3480. Available from: https://doi.org/10.3846/transport.2019.8577

[23] LEITNER, B., FIGULI, L. Fatigue life prediction of mechanical structures under stochastic loading. In: 22nd Slovak-Polish Scientific Conference on Machine Modelling and Simulations MMS: proceedings. 2017.

[24] HERNANDEZ-ALCANTARA, D., MORALES-MENENDEZ, R., AMEZQUITA-BROOKS, L., SENAME, O., DUGARD, L. Fault estimation methods for semi-active suspension systems. In: 17th IEEE International Autumn Meeting on Power, Electronics and Computing ROPEC 2015: proceedings. IEEE. 2015. ISBN 978-1-4673-7121-6.

[25] SAGA, M., JAKUBOVICOVA, L. Simulation of vertical vehicle non-stationary random vibrations considering various speeds. Scientific Journal of Silesian University of Technology-Series Transport. 2014, 84, p. 113-118. ISSN 0209-3324, eISSN 2450-1549.

[26] HAUSER, V., NOZHENKO, O., KRAVCHENKO, K., LOULOVA, M., GERLICI, J., LACK, T. Impact of three axle boxes bogie to the tram behavior when passing curved track. In: 12th International Scientific Conference of Young Scientists on Sustainable, Modern and Safe Transport TRANSCOM 2017: proceedings. 2017. ISBN 9781510843349, p. 295-300.

[27] STASTNIAK, P., MORAVCIK, M. Stability investigation of a new balance beam system solution for a 3-axle railway bogie. In: 24th International Conference on Current Problems in Rail Vehicles PRORAIL 2019: proceedings. 2019. p. 309-318.

[28] SMETANKA, L., HRCEK, S., STASTNIAK, P. Investigation of railway wheelset profile wear by using computer simulation. In: 23rd Polish-Slovak Scientific Conference on Machine Modelling and Simulations MMS: proceedings. 2018.

[29] WEYSSENHOFF, A., OPALA, M., KOZIAK, S., MELNIK, R. Characteristics and investigation of selected manufacturing defects of passenger car tires. In: 13th International Scientific Conference on Sustainable, Modern and Safe Transport TRANSCOM 2019: proceedings. 2019. p. 119-126.

[30] KRAVCHENKO, K., SAKNO, O., LUKICHOV, A. Research of dynamics of tire wear of trucks and prognostication of their service life. Transport Problems. 2012, 7(4), p. 85-94. eISSN 2300-861X.

[31] KOSTRZEWSKI, M. Analysis of selected acceleration signals measurements obtained during supervised service conditions - study of hitherto approach. Journal of Vibroengineering [online]. 2018, 20(4), p. 1850-1866. ISSN 1392-8716, eISSN 2538-8460. Available from: https://doi.org/10.21595/jve.2018.19367

[32] HARUSINEC, J., SUCHANEK, A., LOULOVA, M., KURCIK, P. Design of a prototype frame of an electrically driven three-wheel vehicle. In: 23rd Polish-Slovak Scientific Conference on Machine Modelling and Simulations MMS: proceedings. 2018.

[33] HAUSER, V., NOZHENKO, O., KRAVCHENKO, K., LOULOVA, M., GERLICI, J., LACK, T. Proposal of a steering mechanism for tram bogie with three axle boxes. In: 12th International Scientific Conference of Young Scientists on Sustainable, Modern and Safe Transport TRANSCOM 2017: proceedings. 2017. p. 289-294.

[34] DROZDZIEL, P., KOMSTA, H., KRZYWONOS, L. Repair costs and the intensity of vehicle use. Transport Problems. 2013, 8(3), p. 131-138. eISSN 2300-861X.

[35] CABAN, J., DROZDZIEL, P., KRZYWONOS, L., RYBICKA, I., SARKAN, B., VRABEL, J. Statistical analyses of selected maintenance parameters of vehicles of road transport companies. Advances in 
Science and Technology-Research Journal [online]. 2019, 13(1), p. 1-13. ISSN 2299-8624. Available from: https://doi.org/10.12913/22998624/92106

[36] JEREMENKO, V.S., SHEGEDIN, P.A., PEREJODENKO, A.V. Development of a diagnostic system for damping characteristics of rolling stock vibration shock absorbers (In Russian). East European Advanced Technology Journal [online]. 2014, 5/7(71), p. 10-15. ISSN 1729-3774, eISSN 1729-4061. Available from: http://journals.uran. ua/eejet/article/view/27818/25377

[37] PARK, C H., KIM, S., LEE, J., LEE, D.-K., NA, K., SONG, J., YOUN, B. D. Hybriding data-driven and modelbased approaches for fault diagnosis of rail vehicle suspensions. In: 9th Annual Conference of the Prognostics and Health Management Society PHM 2017: proceedings. 2017. P. 612-620.

[38] BORJAK, K. F., MANZARUK, M. A. Different approaches to the evaluation of technical condition of the hydraulic shock absorbers. In: 4th International Partner Conference Innovative Solutions for Railway Rolling Stock: Practice, Results of Implementation EUROTRAIN 2013: proceedings. 2013.

[39] WANG, Y.-X., CHEN, E.-L., QI, Z., LIU, P.-F., ZHANG, L. Analysis of dynamic behaviour of high-speed railway vehicle with faulty anti-hunting shock absorber. Journal of Advances in Vehicle Engineering. 2017, 3(3). ISSN 2423-7345.

[40] Passport STR 02-01.00.000. PS: Stand for testing dampers hydraulic railway rolling stock. Limited Liability Company "Diesel-Test-Kit".

[41] RYKOV, S. P., TARASJUK, V. N., KOVALS, V. S., KUPRIJANOV, A. P. Modeling and evaluation of the damping capacity of hydraulic shock absorbers (In Russian). Systems. Methods. Technologies [online]. 2013, 20(3), p. 27-32. ISSN 2077-5415. Available from: https://brstu.ru/static/unit/journal_smt/docs/number_20/27-32.pdf

[42] DOBROWOLSKI, D., DROZDZIEL, P., MADLENAK, R., SILUCH, D., RYBICKA, I. Daily kilometrage analysis for selected vehicle groups. Advances in Science and Technology-Research Journal [online]. 2018, 12(3), p. 39-46. ISSN 2299-8624. Available from: https://doi.org/10.12913/22998624/92109

[43] KOZIAK, S., CHUDZIKIEWICZ, A., OPALA, M., MELNIK, R. Virtual software testing and certification of railway vehicle from the point of view of their dynamics. In: 13th International Scientific Conference on Sustainable, Modern and Safe Transport TRANSCOM 2019: proceedings. 2019. p. 729-736.

[44] SAPIETOVA, A., SAGA, M., STANCEKOVA, D., SAPIETA, M. Contribution to numerical study of vehicle vertical stochastic vibration. In: 22nd Slovak-Polish Scientific Conference on Machine Modelling and Simulations MMS 2017: proceedings. 2017.

[45] MORATO, M. M., SENAME, O., DUGARD, L. LPV-MPC fault tolerant control of automotive suspension dampers. IFAC - PapersOnLine [online]. 2018, 51(26), p. 31-36. ISSN 2405-8963. Available from: https://doi.org/10.1016/j.ifacol.2018.11.172

[46] LACK, T., GERLICI, J. Integration methods for rail vehicle ride dynamics solution assessment. In: 23rd International Conference on Current Problems in Rail Vehicles: proceedings. 2017. p. 217-234.

[47] LOVSKA, A., GERLICI, J., FOMIN, O., KRAVCHENKO, K., FOMINA, Y., LACK, T. Special aspects of determining the dynamic load of the tank container during its transportation in an integrated train set by a railway ferry. In: 11th Transbaltica International Scientific Conference Transbaltica 2019: proceedings. 2019, p. $581-590$.

[48] MELNIK, R., KOSTRZEWSKI, M. Rail vehicle's suspension monitoring system - analysis of results obtained in tests of the prototype. In: 2nd International Conference on Smart Diagnostics of Structures: proceedings. 2012, p. 281-288.

[49] LEITNER, B., MOCOVA, L., HROMADA, M. A new approach to identification of critical elements in railway infrastructure. In: 10th International Scientific Conference on Transportation Science and Technology Transbaltica 2017: proceedings. 2017. p. 143-149.

[50] BUREIKA, G., GAIDAMAUSKAS, E., KUPINAS, J., BOGDEVICIUS, M., STEISUNAS, S. Modelling the assessment of traffic risk at level crossing of Lithuanian Railways. Transport [online]. 2017, 32(3), p. 282-290. ISSN 0209-3324, eISSN 2450-1549. Available from: https://doi.org/ 10.3846/16484142.2016.1244114

[51] STEISUNAS, S., BUREIKA, G. Study of freight wagon running dynamic stability taking into account the track stiffness variation. Transport Problems. 2014, 9(4), p. 131-143. eISSN 2300-861X. 